\title{
Production of Ethanol From Newly Developed and Improved Winter Barley Cultivars
}

\author{
Nhuan P. Nghiem ${ }^{1} \cdot$ Wynse S. Brooks ${ }^{2}$. \\ Carl A. Griffey ${ }^{2} \cdot$ Matthew J. Toht $^{1}$
}

Received: 9 September 2016 / Accepted: 10 November 2016 /

Published online: 23 November 2016

(C) Springer Science+Business Media New York (outside the USA) 2016

\begin{abstract}
Winter barley has attracted strong interest as a potential feedstock for fuel ethanol production in regions with mild winter climate such as the mid-Atlantic and northeastern USA. Ten recently developed and improved winter barley cultivars and breeding lines including five hulled and five hull-less lines were experimentally evaluated for potential ethanol production. The five hulled barley lines included three released cultivars (Thoroughbred, Atlantic, and Secretariat) and two breeding lines (VA09B-34 and VA11B-4). The five hull-less lines also included three released cultivars (Eve, Dan, and Amaze 10) and two breeding lines (VA08H-65 and VA13H-34). On the average, the hull-less barley cultivars produced more ethanol per unit mass because of their higher starch and $\beta$-glucan contents. However, since the hulled barley cultivars had higher agronomic yield, the potential ethanol production per acre of land for the two types were approximately equal. Among the ten cultivars tested, the hull-less cultivar Amaze 10 was the best one for ethanol production. The ethanol yield values obtained for this cultivar were 2.61 gal per bushel and 292 gal per acre.
\end{abstract}

Keywords Winter barley $\cdot$ Fuel ethanol $\cdot$ Fermentation $\cdot$ Starch hydrolysis $\cdot \beta$-Glucan hydrolysis

Mention of trade names or commercial products in this article is solely for the purpose of providing specific information and does not imply recommendation or endorsement by the US Department of Agriculture (USDA). The USDA is an equal employment provider and employer.

Nhuan P. Nghiem

john.nghiem@ars.usda.gov

1 Sustainable Biofuels and Co-products Research Unit, Eastern Regional Research Center, Agricultural Research Service, USDA, Wyndmoor, PA 19038, USA

2 Department of Crop and Soil Environmental Sciences, Virginia Polytechnic Institute and State University, Blacksburg, VA 24061, USA 


\section{Introduction}

Economic and political factors have contributed to the increased interest in development of alternative liquid fuels that can be produced from renewable resources throughout the world. Among these, ethanol has attracted the most attention. The USA and Brazil are the two countries with the largest ethanol production. The annual ethanol outputs in the USA and Brazil in 2014 were 99.1 billion liters (14.3 billion gallons) and 23.4 billion liters (6.2 billion gallons), which accounted for 58.2 and $25.2 \%$ of the total world production, respectively [1]. In the USA, corn is the main feedstock for ethanol production. In 2015, $98 \%$ of all the ethanol produced in the USA came from corn [2]. The majority of the ethanol plants in the USA are in the Midwest where most of the corn farms are located. Attempts have been made to develop feedstocks that can be grown in other regions of the country where fuel ethanol is also needed. Whereas sweet and grain sorghum have been identified as potential feedstocks in the south [3], winter barley (Hordeum vulgare L.) has attracted attention as a potential feedstock in the Northeast and mid-Atlantic [4].

In addition to potential use as a feedstock for ethanol production, winter barley also has many economic and environmental benefits. Late May or early June harvest of winter barley allows a full soybean crop to be grown afterwards in the same crop year, which will be followed by corn and then winter barley again the year after. This practice will allow a two -year, threecrop rotation, which ultimately results in more grain being produced on the same acreage with less nutrient loss to watersheds and sensitive areas such as the Chesapeake Bay [5-8].

One of the problems of using barley for ethanol production is the presence of the mixed linkage $(1,3)(1,4)$ - $\beta$-D-glucans in the grain. During the preparation of the mash for fermentation, these polymers become solubilized and cause considerable increase in the mash viscosity. Various $\beta$-glucanases were added to the mash in attempt to address this issue. Addition of these enzymes helped to reduce the viscosity of the mash but did not increase ethanol yield [9]. When both commercial $\beta$-glucanases and a developmental $\beta$-glucosidase were added to the mash of Thoroughbred (a hulled barley cultivar), additional ethanol production was observed. It was demonstrated that the added $\beta$-glucanases hydrolyzed $\beta$-glucans to oligomers and the added $\beta$-glucosidase further hydrolyzed these oligomers to glucose, which was readily fermentable by the yeast Saccharomyces cerevisiae [4]. The fermentation process, which was developed using shake flasks, was successfully scaled up in 7.5-, 70-, and 300-L fermentors using both hulled (Thoroughbred) and hull-less barley (Eve) [10]. An economic analysis of this process indicated the benefit of adding the enzymes to obtain extra ethanol production in all cases except one where the highest $\beta$-glucosidase cost allowance and lowest barley cost were used [11]. Recently, barley was given the status of a conventional renewable fuel and an advanced renewable fuel if certain process technologies are used for ethanol production by the US Environmental Protection Agency (EPA) [12].

Collaborative efforts between researchers at the Virginia Polytechnic Institute and State University (Virginia Tech) and those at the Eastern Regional Research Center (ERRC) of the US Department of Agriculture's Agriculture Research Service have resulted in development of many new and improved winter barley cultivars for use in feed, food, and ethanol production. The grain composition and other pertinent information have been reported in a recent publication [13]. Our main objective was to determine the potential use of the newly developed barley lines for improvement of ethanol production compared to the results obtained with the old cultivars in previous studies $(4,10)$. In the present study, we report the results of ethanol fermentation experiments using five hulled and five hull-less winter barley lines that have 
recently been developed. The potential ethanol production and use of the distillers dried grains with solubles (DDGS) co-product in feed application are also discussed.

\section{Materials and Methods}

\section{Materials}

A total of ten (five hulled and five hull-less) winter barley cultivars and advanced breeding lines obtained from the Virginia Tech breeding program were used in this study. The five hulled lines evaluated in the study included three released cultivars (Thoroughbred, Atlantic, and Secretariat) and two breeding lines (VA09B-34 and VA11B-4). The five hull-less lines also included three released cultivars (Eve, Dan, and Amaze 10) and two breeding lines (VA08H-65 and VA13H-34). These lines were selected based on results from previous grain composition analyses of barley genotypes conducted by the ERRC. All barley cultivars and advanced lines were grown in the 2013-2014 growing season under identical field conditions at the Eastern Virginia Agriculture Research and Extension Center (EVAREC) near Warsaw, VA, USA $\left(37.989433^{\circ} \mathrm{N}\right.$, $76.77549^{\circ} \mathrm{W}$ ), in replicated yield trials using a randomized complete block design and recommended standard management and fertilizer application protocols for small-grain production [14]. Conventional-till yield plots were composed of seven rows with $15.2 \mathrm{~cm}$ between rows. The harvested plot length was $2.74 \mathrm{~m}$. Tests were planted at 28 seeds per $0.304 \mathrm{~m}$ of row. Grain was harvested on June 8, 2014, using a small research plot Wintersteiger Combine Classic (Wintersteiger AG, Germany). Four hundred grams per entry of grain sample was cleaned using a de-bearder machine and a Hege air screen cleaner prior to sending samples for chemical analysis. Samples were sent from the EVAREC to the ERRC in sealed plastic bags. Upon receiving, the bags were kept sealed in the laboratory at about $25{ }^{\circ} \mathrm{C}$ until the materials were used in the compositional analysis and fermentation study. The methods used for the compositional analysis are described in the "Analytical Methods" section.

All of the enzymes, which included SPEZYME® XTRA (thermostable $\alpha$-amylase, activity 14,000 units/g), OPTIMASH ${ }^{\mathrm{TM}}$ BG ( $\beta$-glucanase, activity 10,300 units/g), OPTIMASH ${ }^{\mathrm{TM}}$ TBG (thermostable $\beta$-glucanase, activity 5625 units/g), FERMENZYME® L-400 (glucoamylase/protease mix, activity 350 units/g), and a developmental $\beta$-glucosidase (activity 1100 units/g), were provided by DuPont Industrial Biosciences, Palo Alto, CA, USA. The enzymes were kept refrigerated at $4{ }^{\circ} \mathrm{C}$.

Active Dry Ethanol Red was provided by Lesaffre Yeast Corporation, Milwaukee, Wisconsin. The dry yeast powder was kept refrigerated at $4{ }^{\circ} \mathrm{C}$.

All chemicals were of reagent grades and purchased from Sigma-Aldrich, St. Louis, Missouri.

\section{Methods}

Ethanol production was studied in a simultaneous saccharification and fermentation (SSF) process. The details of the experimental procedure are given below.

Barley samples were ground in a Wiley mill fitted with a 1-mm screen. The mash for ethanol fermentation was prepared in batches of $1000 \mathrm{~g}$ total weight. First, moisture content of the ground barley was determined using the method described in the "Analytical Methods" section below. Then, the quantity of ground barley equivalent to $300 \mathrm{~g}$ dry solids was obtained and added to a 2-L beaker containing de-ionized water needed to make a total weight of 
$1000 \mathrm{~g}$. The slurry was stirred with a mechanical agitator. The $\mathrm{pH}$ was adjusted to 5.2 with $2 \mathrm{M}$ sulfuric acid, and three enzymes were added, which included SPEZYME® XTRA, added at $81.2 \mu \mathrm{L}\left(0.30 \mathrm{~kg} / \mathrm{MT}\right.$ dry solids), OPTIMASH ${ }^{\mathrm{TM}} \mathrm{BG}$, added at $35.5 \mu \mathrm{L}(0.13 \mathrm{~kg} / \mathrm{MT}$ dry solids), and OPTIMASH ${ }^{\mathrm{TM}} \mathrm{TBG}$, added at $16.4 \mu \mathrm{L}(0.06 \mathrm{~kg} / \mathrm{MT}$ dry solids). The mash was heated in a constant temperature oil bath. The mash temperature was maintained at $60{ }^{\circ} \mathrm{C}$ for $1 \mathrm{~h}$ (pre-liquefaction) and then at $90{ }^{\circ} \mathrm{C}$ for $3 \mathrm{~h}$ (liquefaction). During this time, small amounts of de-ionized water were intermittently added to compensate for evaporation loss. At the end of the starch liquefaction, the beaker was cooled in a water bath. When the temperature of the mash dropped to about $40{ }^{\circ} \mathrm{C}$, the beaker was weighed and de-ionized water was added to bring the total weight back to $1000 \mathrm{~g}$. The mash was stirred, and its $\mathrm{pH}$ adjusted to 3.8-4.0 with $2 \mathrm{M}$ sulfuric acid. A glucoamylase plus protease mixture, FERMENZYME® L-400, was added at $177 \mu \mathrm{L}\left(0.65 \mathrm{~kg} / \mathrm{MT}\right.$ dry solids) together with OPTIMASH ${ }^{\mathrm{TM}}$ BG at $13.5 \mu \mathrm{L}$ $\left(0.05 \mathrm{~kg} / \mathrm{MT}\right.$ dry solids) and urea $(0.4 \mathrm{~g})$. The main purpose of OPTIMASH ${ }^{\mathrm{TM}}$ BG addition to the cooked mash was to complete the solubilization and liquefaction of the remaining $\beta$ glucans that were not liquefied in the pre-liquefaction and liquefaction steps as a result of deactivation of the two $\beta$-glucanases at $90{ }^{\circ} \mathrm{C}$. The enzyme dosages described above were those recommended by the manufacturer. Stirring of the mash was continued for 20 min to ensure complete dissolution of urea and uniform distribution of the enzymes. Then, the mash was dispensed into $250-\mathrm{mL}$ flasks at $150 \mathrm{~g}$ per flask. The active dry yeast was rehydrated by addition of $2.5 \mathrm{~g}$ to $50 \mathrm{~mL}$ de-ionized water and stirred for $30 \mathrm{~min}$. The yeast slurry was added to the flasks at $0.75 \mathrm{~mL}$ per flask. The initial viable yeast count was about $2 \times 10^{7}$ per gram of dry solids or $5 \times 10^{6}$ per gram of mash. The developmental $\beta$-glucosidase was then added using a dosage of $100 \mu \mathrm{L} /$ flask $(0.37 \mathrm{~kg} / \mathrm{MT}$ dry solids). The flasks were capped with rubber stoppers having an 18-gauge hypodermic needle punctured through to allow for pressure relief. Finally, the flasks were incubated in an orbital shaker maintained at $32{ }^{\circ} \mathrm{C}$ and $200 \mathrm{rpm}$. The fermentation of the barley mash was carried out for $72 \mathrm{~h}$. To avoid sudden disruption of vapor/ liquid equilibrium, which could lead to significant losses of ethanol from the liquid phase, the flasks were kept closed during the course of the fermentation and only final samples were taken for analysis of ethanol and other metabolites. The flasks, however, were weighed periodically and the weight loss due to carbon dioxide production was used to follow the progress of ethanol production. Each experiment was performed in six replicates. At the end of the experiment, the contents of the flasks were combined and dried in an oven at $50{ }^{\circ} \mathrm{C}$. The final DDGS products were subject to compositional analysis using the same procedures used for the barley samples.

\section{Analytical Methods}

The moisture content of whole barley kernels and ground barley samples were determined by drying about $3 \mathrm{~g}$ of materials in a moisture balance (Model MB45, Ohaus, Parsippany, NJ, USA). The determinations were performed in triplicate, and the average results are reported.

The other analyses, which included starch, $\beta$-glucan, oil, protein, fiber, and ash, were performed according to the procedures described in a previous study [10] and are described here.

The ash content was determined by heating barley flour in a muffle furnace at $550{ }^{\circ} \mathrm{C}$ for about 16-20 h until a light gray ash is obtained (AACC 08-01; American Association of Cereal Chemists).

To determine the oil content, barley was ground in a Wiley mill fitted with a 20-mesh screen and 4-g samples were extracted with hexane in an Accelerated Solvent Extractor 
(Dionex Corporation, Sunnyvale, CA). The instrument was operated at 1000 psi and a temperature of $100{ }^{\circ} \mathrm{C}$ for three 10 -min cycles after which the hexane extract obtained was dried under a stream of nitrogen and oil content determined gravimetrically.

For starch analysis, barley samples were ground in a cyclone mill fitted with a $0.5-\mathrm{mm}$ screen (Udy, Ft. Collins, CO) and the flours were analyzed using a starch determination kit (Megazyme International Ireland Ltd., Bray Business Park, Bray, Co. Wicklow, Ireland) (ICC Standard Method No. 168; International Association for Cereal Science and Technology). A YSI 2700 Analyzer (YSI Incorporated, Yellow Springs, OH) fitted with a YSI 2710 turntable was used for automated glucose determination of enzymatically hydrolyzed starch-containing samples.

The protein content of barley flour samples was determined in accordance with standard methods (AOAC 990.03; Association of Official Agricultural Chemists, and AACC 46-30; American Association of Cereal Chemists). The conversion factor used to obtain protein values for barley was 6.25 (AOAC 14.067; Association of Official Agricultural Chemists).

Barley $\beta$-glucan was analyzed using a kit obtained from Megazyme International Ireland Ltd. (Bray Business Park, Bray, Co. Wickow, Ireland) according to ICC Standard Method 166 (International Association for Cereal Science and Technology) and instructions provided by the manufacturer. This method conforms to standard methods (AOAC 995.16; Association of Official Agricultural Chemists, and AACC 32-33; American Association of Cereal Chemists).

Acid detergent fiber (ADF), neutral detergent fiber (NDF), and crude fiber (CF) were determined with an Ankom 2000 fiber analyzer (Ankom Technology, Macedon, NY) as per the methods supplied by the manufacturer.

To determine the concentrations of fermentation products, samples taken from the fermentation flasks were centrifuged and the supernatants were filtered through $0.2-\mu \mathrm{m}$ filters. Residual glucose, ethanol, and other fermentation minor products were determined by highperformance liquid chromatography (HPLC). The system was an Agilent Technologies series 1200 equipped with a refractive index (RI) detector. The column was Aminex ${ }^{\circledR} \mathrm{HPX}-87 \mathrm{H}$ (Bio-Rad Laboratories, Hercules, CA, USA) operated at $60{ }^{\circ} \mathrm{C}$. The solvent was $0.5 \mathrm{wt} \%$ $\mathrm{H}_{2} \mathrm{SO}_{4}$ pumped at a flow rate of $0.6 \mathrm{~mL} / \mathrm{min}$. To determine the final cell counts, the samples were subjected to serial dilution followed by plating on yeast extract/peptone/dextrose (YPD) plates, which then were incubated at $32{ }^{\circ} \mathrm{C}$ for $24 \mathrm{~h}$.

\section{Results and Discussion}

The grain composition and production data of the five hulled and five hull-less winter barley lines are shown in Tables 1 and 2, respectively. Since both starch and $\beta$-glucan could be hydrolyzed with suitable enzymes to produce glucose, which in turn could readily be fermented by $S$. cerevisiae $[4,10]$, a barley feedstock with high total starch plus $\beta$-glucan as well as high grain yield would be ideal for ethanol production. The other components, which included oil, protein, and fiber, although not directly affecting ethanol production, determine the quality of the DDGS co-product.

In general, the hulled barley lines had lower starch contents compared to the hull-less barley lines. The starch contents in the five hulled barley lines varied from 50.2\% (Secretariat) to $57.4 \%$ (Thoroughbred) with an average of $54.2 \%$. The starch contents in the five hull-less barley lines varied from $59.1 \%$ (VA13H-34) to $65.4 \%$ (Eve) with an average of $62.7 \%$. The $\beta$ glucan contents in the hulled and hull-less barley lines were similar. For the hulled barley lines, they varied from 4.4 to $5.2 \%$ with an average of $4.7 \%$ whereas the hull-less lines varied from 
Table 1 Grain composition and production data of the five hulled winter barley lines

\begin{tabular}{lllllll}
\hline Line & Thoroughbred & Atlantic & Secretariat & VA09B-34(LA) & VA11B-4 & Average \\
\hline Grain type & Hulled & Hulled & Hulled & Hulled & Hulled & Value \\
Compositional analysis (\% dry basis) & & & & & \\
Moisture (whole kernel) & $12.6 \pm 0.0$ & $12.9 \pm 0.0$ & $12.9 \pm 0.0$ & $12.8 \pm 0.0$ & $12.5 \pm 0.0$ & 12.7 \\
Moisture (ground sample) & $9.7 \pm 0.0$ & $9.2 \pm 0.0$ & $9.5 \pm 0.1$ & $8.8 \pm 0.0$ & $8.6 \pm 0.0$ & 9.2 \\
Oil (crude fat) & $1.7 \pm 0.1$ & $1.7 \pm 0.0$ & $1.3 \pm 0.1$ & $1.6 \pm 0.2$ & $1.5 \pm 0.1$ & 1.6 \\
Starch & $57.4 \pm 0.0$ & $52.6 \pm 0.0$ & $50.2 \pm 0.0$ & $56.5 \pm 0.0$ & $54.0 \pm 0.0$ & 54.2 \\
$\beta$-Glucan & $4.4 \pm 0.2$ & $4.8 \pm 0.3$ & $5.2 \pm 0.2$ & $4.5 \pm 0.2$ & $4.7 \pm 0.2$ & 4.7 \\
Protein & $7.5 \pm 0.0$ & $8.9 \pm 0.2$ & $8.8 \pm 0.3$ & $9.4 \pm 0.1$ & $8.1 \pm 0.8$ & 8.6 \\
Acid detergent fiber & $5.4 \pm 0.1$ & $6.7 \pm 0.2$ & $6.9 \pm 0.6$ & $6.3 \pm 0.3$ & $6.6 \pm 0.3$ & 6.2 \\
Neutral detergent fiber & $28.4 \pm 2.8$ & $33.4 \pm 4.0$ & $24.7 \pm 1.9$ & $15.8 \pm 0.3$ & $25.4 \pm 4.9$ & 27.3 \\
Crude fiber & $10.6 \pm 0.0$ & $11.4 \pm 0.5$ & $11.0 \pm 0.4$ & $10.6 \pm 1.1$ & $11.1 \pm 0.9$ & 11.0 \\
Yield (bu/ac) & 127.2 & 120.5 & 122.5 & 115.8 & 120.7 & 121.3 \\
Test weight (lb/bu) & 48.8 & 47.4 & 48.6 & 49.3 & 49.4 & 48.7 \\
Yield (lb/ac) & 6207 & 5712 & 5954 & 5709 & 5963 & 5909 \\
\hline
\end{tabular}

4.3 to $5.5 \%$ with an average of $5.1 \%$. Among the five hulled barley lines, Thoroughbred contained the largest amount of fermentable substrates (starch plus $\beta$-glucan) at $61.8 \%$. All five hull-less barley lines had the total starch-plus- $\beta$-glucan contents higher than those in the five hulled barley lines. Three of the hull-less barley lines, i.e., Eve, Dan, and Amaze 10, had the total starch-plus- $\beta$-glucan contents very close to the typical starch content in corn $(\sim 70 \%)$ [2]. In terms of grain yield, the hulled barley lines were slightly better feedstocks with an average yield of $5963 \mathrm{lb} / \mathrm{ac}$ compared to the average yield of $5655 \mathrm{lb} / \mathrm{ac}$ for the hull-less lines. However, one of the five hull-less barley lines, Amaze 10, had the highest yield of $6496 \mathrm{lb} / \mathrm{ac}$, which was $300 \mathrm{lb} / \mathrm{ac}$ higher than the yield of the best hulled winter barley line (Thoroughbred).

Table 2 Grain composition and production data of the five hull-less winter barley lines

\begin{tabular}{lllllll}
\hline Line & EVE & DAN & AMAZE 10 & VA08H-65 & VA13H-34 & Average \\
\hline Grain type & Hull-less & Hull-less & Hull-less & Hull-less & Hull-less & Value \\
Compositional analysis (\% dry basis) & & & & & \\
$\quad$ Moisture (whole kernel) & $12.7 \pm 0.0$ & $12.8 \pm 0.0$ & $12.6 \pm 0.0$ & $12.6 \pm 0.0$ & $12.5 \pm 0.0$ & 12.6 \\
Moisture (ground sample) & $11.2 \pm 0.0$ & $11.1 \pm 0.0$ & $10.8 \pm 0.0$ & $10.7 \pm 0.0$ & $9.0 \pm 0.0$ & 10.6 \\
Oil (crude fat) & $1.8 \pm 0.0$ & $1.9 \pm 0.1$ & $2.3 \pm 0.0$ & $1.9 \pm 0.0$ & $1.8 \pm 0.0$ & 1.9 \\
Starch & $65.4 \pm 0.0$ & $64.9 \pm 0.0$ & $64.2 \pm 0.0$ & $60.0 \pm 0.0$ & $59.1 \pm 0.0$ & 62.7 \\
ß-Glucan & $4.3 \pm 0.1$ & $5.2 \pm 0.1$ & $5.2 \pm 0.2$ & $5.3 \pm 0.2$ & $5.5 \pm 0.2$ & 5.1 \\
Protein & $9.2 \pm 0.3$ & $9.0 \pm 0.1$ & $8.6 \pm 0.0$ & $9.5 \pm 0.1$ & $9.2 \pm 0.8$ & 9.1 \\
Acid detergent fiber & $2.0 \pm 0.5$ & $2.1 \pm 0.3$ & $2.0 \pm 0.4$ & $2.4 \pm 0.2$ & $2.1 \pm 0.3$ & 2.1 \\
Neutral detergent fiber & $26.7 \pm 5.2$ & $18.6 \pm 4.3$ & $10.7 \pm 1.0$ & $16.3 \pm 2.0$ & $23.2 \pm 0.5$ & 19.6 \\
Crude fiber & $7.0 \pm 0.7$ & $8.2 \pm 0.0$ & $7.8 \pm 0.4$ & $7.8 \pm 0.7$ & $7.3 \pm 0.1$ & 7.6 \\
Yield (bu/ac) & 87.9 & 97.1 & 112.0 & 101.6 & 88.6 & 97.4 \\
Test weight (lb/bu) & 58.1 & 58.9 & 58.0 & 58.6 & 56.4 & 58.0 \\
Yield (lb/ac) & 5107 & 5719 & 6496 & 5954 & 4997 & 5655 \\
\hline
\end{tabular}


There were no significant differences in the oil contents and protein contents of the hulled and hull-less barley lines. The average value of oil content in the five hulled barley lines was $1.6 \%$ compared to $1.9 \%$ in the five hull-less barley lines. Similarly, the average value of protein content in the five hulled barley lines was $8.6 \%$ compared to $9.1 \%$ in the five hull-less barley lines. Feeds for monogastric animals having lower NDF and ADF are preferred [15]. On this basis, the hull-less barley lines were better feedstocks for production of the DDGS coproducts since they contained both lower NDF and lower ADF. The average values of the $\mathrm{NDF}$ and ADF in the hull-less barley lines were 19.6 and $2.1 \%$, respectively, compared to the corresponding average values of 27.3 and $6.2 \%$ in the hulled barley lines.

The results of the ethanol fermentation experiments are shown in Tables 3 and 4 for the hulled and hull-less barley lines, respectively. The final ethanol concentrations calculated from weight-loss measurements and determined directly by HPLC were both given for comparison. The HPLC results were slightly lower than the calculated results. The differences, however, were less than $5 \%$ in all experiments with the lowest value of $0.7 \%$ obtained in case of VA13H-34 (Table 4). The weight-loss measurements, therefore, offered a simple method to follow the progress of fermentation without having to frequently remove and analyze samples. In all of the experiments, the fermentation process proceeded at high efficiencies with the lowest ethanol yield of $79.8 \%$ of the theoretical value obtained for DAN (Table 4) and the highest yield of $94.2 \%$ obtained for VA11B-4 (Table 3). The average ethanol yields were 91.0 and $87.7 \%$ of the theoretical values for the hulled and hull-less barley lines, respectively. Because of higher starch contents, the ethanol yields in terms of gallons per bushel for the hull-less barley lines were significantly higher than those obtained for the hulled barley lines. The average values obtained for the hull-less and the hulled barley lines were 2.5 and $1.9 \mathrm{gal} / \mathrm{bu}$., respectively. These values for the hull-less cultivars are the highest ever reported for barley grain [16] and are approaching the yields reported from fully optimized commercial corn grain ethanol plants. In terms of gallons of ethanol produced per acre of land, the hull-less winter barley lines were slightly better with an average yield of $246 \mathrm{gal} / \mathrm{ac}$ compared to the average yield of $234 \mathrm{gal} / \mathrm{ac}$ obtained with the hulled barley lines. While these values are much lower than that expected from corn grain, where values of ethanol yield over $400 \mathrm{gal} / \mathrm{ac}$ are common, corn is a single season crop and winter barley is just one of two crops harvested from the same field in the same year. Among all the winter

Table 3 Ethanol production from the five hulled winter barley lines

\begin{tabular}{|c|c|c|c|c|c|c|}
\hline Line & Thoroughbred & Atlantic & Secretariat & $\begin{array}{l}\text { VA09B-34 } \\
\text { (LA) }\end{array}$ & VA11B-4 & Average \\
\hline Grain type & Hulled & Hulled & Hulled & Hulled & Hulled & Value \\
\hline \multicolumn{7}{|l|}{ Final ethanol $(\% v / v)$} \\
\hline Theoretical $^{\mathrm{a}}$ & 16.4 & 15.4 & 14.9 & 16.2 & 15.7 & 15.7 \\
\hline Calculated from weight loss & $15.4 \pm 0.1$ & $14.2 \pm 0.1$ & $14.3 \pm 0.2$ & $14.9 \pm 0.1$ & $15.2 \pm 0.1$ & 14.8 \\
\hline Determined by HPLC & $14.8 \pm 0.1$ & $13.7 \pm 0.2$ & $13.8 \pm 0.1$ & $14.5 \pm 0.1$ & $14.8 \pm 0.1$ & 14.3 \\
\hline Yield (\% theoretical) & 90.0 & 89.0 & 92.2 & 89.5 & 94.2 & 91.0 \\
\hline Yield (gal/bu) & 2.0 & 1.8 & 1.8 & 2.0 & 2.0 & 1.9 \\
\hline Yield (gal/ac) & 255 & 215 & 226 & 230 & 246 & 234 \\
\hline
\end{tabular}

${ }^{\text {a }}$ Based on total starch plus $\beta$-glucans 
Table 4 Ethanol production from the five hull-less winter barley lines

\begin{tabular}{lllllll}
\hline Line & EVE & DAN & AMAZE 10 & VA08H-65 & VA13H-34 & Average \\
\hline $\begin{array}{llllll}\text { Grain type } \\
\text { Final ethanol }(\% v / v)\end{array}$ & Hull-less & Hull-less & Hull-less & Hull-less & Hull-less & Value \\
$\quad$ Theoretical & & & & & & \\
$\quad$ Calculated from weight loss $^{\mathrm{a}}$ & 18.2 & 18.0 & 18.1 & 17.2 & 17.0 & 17.7 \\
$\quad$ Determined by HPLC $_{\text {Yield (\% theoretical) }}^{\mathrm{a}}$ & $16.1 \pm 0.1$ & $14.9 \pm 1.8$ & $16.5 \pm 0.1$ & $16.2 \pm 0.1$ & $15.6 \pm 0.1$ & 15.9 \\
Yield (gal/bu) & 88.6 & 79.8 & 88.2 & 90.5 & 91.3 & 87.7 \\
Yield (gal/ac) & 2.6 & 2.3 & 2.6 & 2.6 & 2.5 & 2.5 \\
\hline
\end{tabular}

${ }^{\text {a }}$ Based on total starch plus $\beta$-glucans

barley lines tested, AMAZE 10 stood out as the best feedstock with the highest ethanol yield. The yield of $292 \mathrm{gal} / \mathrm{ac}$ obtained for this feedstock was considerably higher than the values obtained for Thoroughbred (255 gal/ac) and EVE (231 gal/ac), which were the two barley lines used for development of the fermentation process in the previous studies $[4,10]$.

As discussed previously, samples were not taken from the flasks to avoid loss of ethanol from the liquid phase. The progress of the fermentation, however, was followed by determining the weight loss due to production of $\mathrm{CO}_{2}$, which was directly proportional to ethanol production. For illustration, the weight loss and calculated ethanol concentration profiles for AMAZE 10 are shown in Fig. 1. The results indicated that, in practice, the fermentation probably could be ended at around $48-50 \mathrm{~h}$ where more than $95 \%$ of the total ethanol had been produced. The average

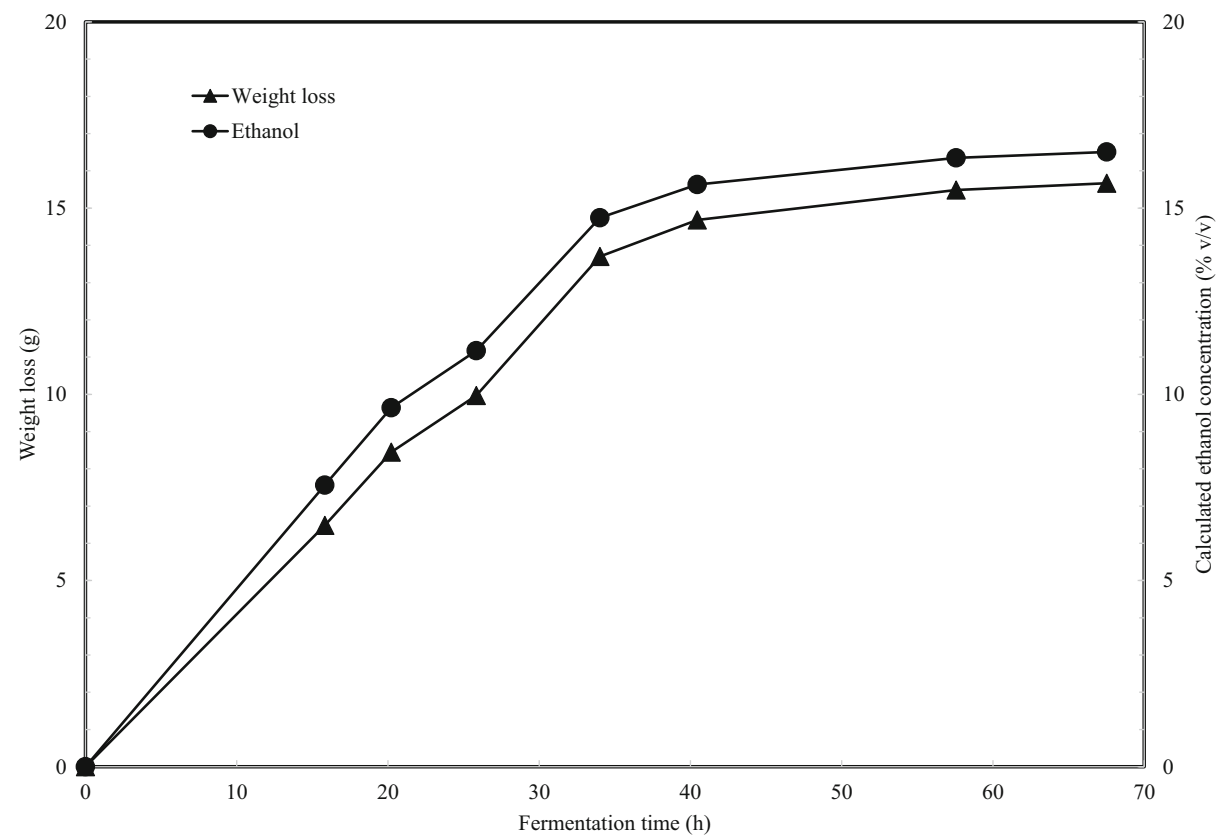

Fig. 1 Weight loss due to $\mathrm{CO}_{2}$ production and calculated ethanol concentration in AMAZE 10 fermentation 
Table 5 Concentrations of products and mass balance in AMAZE 10 fermentation

\begin{tabular}{llll}
\hline Products & Concentration $(\mathrm{g} / \mathrm{L})$ & Mass $(\mathrm{g})$ & Carbon content $(\mathrm{g})$ \\
\hline Glucotriose & 2.73 & 0.33 & 0.14 \\
Maltose & 1.52 & 0.18 & 0.08 \\
Glucose & 0.61 & 0.07 & 0.03 \\
Succinic acid & 2.2 & 0.27 & 0.11 \\
Lactic acid & 0.72 & 0.09 & 0.03 \\
Glycerol & 10.12 & 1.23 & 0.48 \\
Acetic acid & 0.44 & 0.05 & 0.01 \\
Ethanol & 160 & 15.32 & 7.99 \\
Carbon dioxide & & 14.65 & 4.00 \\
Total carbon in products $\mathrm{C}_{\mathrm{P}}(\mathrm{g})$ & & & 12.87 \\
Total carbon input $\mathrm{C}_{\mathrm{I}}(\mathrm{g})$ & & & 12.84 \\
$\mathrm{C}_{\mathrm{P}} / \mathrm{C}_{\mathrm{I}}$ ratio & & & 1.00 \\
\hline
\end{tabular}

viable cell counts in the final samples taken from the AMAZE 10 flasks was $1.8 \times 10^{8}$ cells/g mash, which was only two logs increase and atypical of relatively low growth of yeast culture in ethanol fermentation. The average concentrations of ethanol and other fermentation products in the final samples taken from the AMAZE 10 flasks are shown in Table 5. A mass balance was performed on the carbon contents in the substrates (i.e., starch plus $\beta$-glucan) and products. The results indicated that all the carbon in the substrates was accounted for.

The compositions of the DDGS obtained from the five hulled and five hull-less barley lines are shown in Tables 6 and 7, respectively. The extremely low values of residual starch contents in all cases indicated that the conversion of starch was practically completed. The $\beta$-glucan contents in the DDGS were all significantly lower than the corresponding values in the starting materials indicating considerable conversion of this substrate. It was estimated that approximately about $75 \%$ of the original $\beta$-glucan was hydrolyzed and fermented. The oil, protein, and fiber contents in the DDGS were all higher than the corresponding values in the starting materials as a result of the concentration effect, which was caused by the conversion of virtually all the starch and most of the $\beta$-glucan. On the average, the hull-less barley DDGS had better monogastric feed qualities due to their higher protein and oil contents and lower NDF and ADF.

Table 6 Composition of the DDGS co-products generated in the fermentation of the five hulled winter barley lines

\begin{tabular}{lllllll}
\hline Line & Thoroughbred & Atlantic & Secretariat & VA09B-34(LA) & VA11B-4 & Average \\
\hline Grain type & Hulled & Hulled & Hulled & Hulled & Hulled & Value \\
Compositional analysis (\% dry basis) & & & & & \\
$\quad$ Oil (crude fat) & $3.7 \pm 0.2$ & $3.5 \pm 0.0$ & $2.1 \pm 0.0$ & $3.9 \pm 0.1$ & $3.3 \pm 0.0$ & 3.1 \\
Starch & $0.9 \pm 0.0$ & $0.4 \pm 0.0$ & $0.3 \pm 0.0$ & $0.4 \pm 0.0$ & $0.4 \pm 0.0$ & 0.5 \\
$\beta$-Glucan & $2.5 \pm 0.1$ & $2.7 \pm 0.1$ & $1.1 \pm 0.1$ & $3.4 \pm 0.0$ & $2.1 \pm 0.1$ & 2.3 \\
Protein & $25.6 \pm 0.2$ & $27.5 \pm 1.3$ & $32.7 \pm 0.2$ & $33.0 \pm 0.9$ & $28.6 \pm 0.0$ & 29.5 \\
Acid detergent fiber & $30.8 \pm 1.0$ & $31.5 \pm 0.1$ & $37.1 \pm 1.1$ & $28.2 \pm 1.1$ & $31.7 \pm 0.7$ & 31.9 \\
Neutral detergent fiber & $51.7 \pm 0.1$ & $53.5 \pm 0.1$ & $57.9 \pm 1.4$ & $47.3 \pm 1.2$ & $50.8 \pm 0.3$ & 52.2 \\
Crude fiber & $13.9 \pm 1.2$ & $23.8 \pm 2.3$ & $13.6 \pm 0.1$ & $12.7 \pm 0.6$ & $13.3 \pm 1.1$ & 15.5 \\
\hline
\end{tabular}


Table 7 Composition of the DDGS co-products generated in the fermentation of the five hull-less winter barley lines

\begin{tabular}{lccllll}
\hline Line & EVE & DAN & AMAZE 10 & VA08H-65 & VA13H-34 & Average \\
\hline Grain type & Hull-less & Hull-less & Hull-less & Hull-less & Hull-less & Value \\
$\begin{array}{l}\text { Compositional analysis (\% dry basis) } \\
\quad\end{array}$ & & & & & \\
$\quad$ Oil (crude fat) & $5.2 \pm 0.1$ & $5.4 \pm 0.2$ & $6.2 \pm 0.1$ & $4.3 \pm 0.1$ & $4.4 \pm 0.0$ & 5.1 \\
Starch & $0.3 \pm 0.0$ & $2.2 \pm 0.0$ & $0.4 \pm 0.0$ & $0.7 \pm 0.0$ & $0.3 \pm 0.0$ & 0.8 \\
$\quad \begin{array}{l}\text {-Glucan } \\
\text { Protein }\end{array}$ & $2.2 \pm 0.1$ & $2.7 \pm 0.1$ & $3.1 \pm 0.1$ & $3.1 \pm 0.1$ & $4.5 \pm 0.1$ & 3.1 \\
Acid detergent fiber & $29.9 \pm 0.6$ & $32.6 \pm 3.2$ & $32.0 \pm 3.7$ & $37.2 \pm 1.8$ & $36.3 \pm 0.2$ & 37.0 \\
Neutral detergent fiber & $43.9 \pm 0.8$ & $45.7 \pm 0.2$ & $42.8 \pm 0.1$ & $41.9 \pm 0.8$ & $43.3 \pm 1.4$ & 43.5 \\
Crude fiber & $8.1 \pm 0.1$ & $10.7 \pm 2.0$ & $10.3 \pm 2.4$ & $6.9 \pm 0.9$ & $11.4 \pm 1.0$ & 9.5 \\
\hline
\end{tabular}

\section{Conclusions}

Ten newly developed and improved winter barley cultivars and breeding lines were tested for potential use as feedstocks for ethanol production. Among these were five hulled and five hullless barley lines. On the average, the hull-less barley cultivars produced more ethanol per unit mass because of their higher starch and $\beta$-glucan contents. However, since the hulled barley cultivars had higher yield, the potential ethanol production per acre of land for the two types was approximately equal. Among the ten cultivars tested, Amaze 10 was the best one for ethanol production. The ethanol yield values obtained for this cultivar were 2.61 gal per bushel, the highest ever reported for a fermentation using barley grain, and 292 gal per acre. The DDGS from Amaze 10 also contained over $45 \%$ protein, making it a very valuable highprotein feed component.

Acknowledgements The authors would like to thank Dr. Kevin Hicks of the USDA ARS ERRC for his critical review of the original manuscript.

\section{References}

1. Anonymous (2015). World fuel ethanol production. Renewable Fuels Association (RFA). http://www. ethanolrfa.org/resources/industry/statistics/\#1456770302650-ba1c280f-bad8. Accessed March 2016.

2. Anonymous (2016). Pocket guide to ethanol 2016. Renewable Fuels Association (RFA). http://www. ethanolrfa.org/wp-content/uploads/2016/02/10823-RFA.pdf. Accessed March 2016.

3. Nghiem, N. P., Montanti, J. M., \& Johnston, D. (2016). Sorghum as a renewable feedstock for production of fuels and industrial chemicals. AIMS Bioengineering, 3, 75-91.

4. Nghiem, N. P., Hicks, K. B., Johnston, D. B., Senske, G., Kurantz, M., Li, M., Shetty, J., \& KoniecznyJanda, G. (2010). Production of ethanol from winter barley by the EDGE (enhanced dry grind enzymatic) process. Biotechnology for Biofuels, 3, 8 .

5. Chesapeake Bay Commission (2007). Biofuels and the bay-getting it right to benefit farms, forest and the Chesapeake: a report of the Chesapeake Bay Commission.

6. Rotz, C. A., Roth, G. W., \& Stout, W. L. (2002). Economic and environmental implications production and use on Pennsylvania dairy farms. Applied Engineering in Agriculture, 18, 417-428.

7. Thelen, K. D., \& Leep, R. H. (2002). Integrating a double-cropped winter annual forage into a corn-soybean rotation. On line. Crop Management. doi:10.1094/CM-2002-1218-01-RS. 
8. McNeal, F. M. (2014). Winter barley can serve as an economically feasible ethanol feedstock. MS Thesis, Humboldt State University, Arcata, California, USA.

9. Ingledew, W. M., Jones, A. M., Bhatty, R. S., \& Rossnagel, B. G. (1995). Fuel alcohol production from hullless barley. Cereal Chemistry, 72, 147-150.

10. Nghiem, N. P., Taylor, F., Johnston, D. B., Shetty, J. K., \& Hicks, K. B. (2011). Scale-up of ethanol production from winter barley by the EDGE (enhanced dry grind enzymatic) process in fermentors up to 3001. Applied Biochemistry Biotechnology, 165, 870-882.

11. Nghiem, N. P., Ramirez, E. C., McAloon, A. J., Yee, W., Johnston, D. B., \& Hicks, K. B. (2011). Economic analysis of fuel ethanol production from winter hulled barley by the EDGE (enhanced dry grind enzymatic) process. Bioresource Technology, 102, 6696-6701.

12. Voegele, E. (2013). EPA publishes notice of data availability for barley ethanol. Ethanol Producer Magazine, July 12, 2013. http://ethanolproducer.com/articles/10052/epa-publishes-notice-of-dataavailability-for-barley-ethanol. Accessed May 2016.

13. Griffey, C., Brooks, W., Kurantz, M., Thomason, W., Taylor, F., Obert, D., Moreau, r., Flores, R., Sohn, M., \& Hicks, K. (2010). Grain composition of Virginia winter barley and implications for use in feed, food, and biofuels production. Journal of Cereal Science, 51, 41-49.

14. Brann, D. E., Holshouser, D. L. and Mullins, G. L. (2000). Agronomy handbook. Publication No. 424-100, Virginia Cooperative Extension, Virginia Tech, Blacksburg, Virginia. https://pubs.ext.vt.edu/424/424-100 /424-100.html. Accessed March 2016.

15. Rasby, R. (2016). Understanding feed analysis. Institute of Agriculture and Natural Resources, University of Nebraska-Lincoln. http://beef.unl.edu/learning/feedanalysis.shtml. Accessed May 2016.

16. Hicks, K. B., Montanti, J., \& Nghiem, N. P. (2014). Use of barley grain and straw for biofuels and other industrial uses. In P. R. Shewry \& S. E. Ullrich (Eds.), Barley chemistry and technology (pp. 269-292). St. Paul, Minnesota: AACC International, Inc.. 